\title{
Purification, Characterization and Immobilization of Lipase from Proteus vulgaris OR34 for Synthesis of Methyl Oleate
}

\author{
Asmae Misbah ${ }^{1 *}$, Saad Ibnsouda Koraichi ${ }^{1,2}$, and Mohamed Ali Tahri Jouti ${ }^{1}$ \\ ${ }^{1}$ Microbial Biotechnology Laboratory, Faculty of Sciences and Technologies, Sidi Mohamed Ben Abdellah University, B.P 2202, Fez, Morocco \\ ${ }^{2}$ Regional University Center of Interface, Sidi Mohamed Ben Abdellah University, B.P. 2626, 30000 Fez, Morocco
}

Received: March 27, 2020 / Revised: May 29, 2020 / Accepted: September 7, 2020

\begin{abstract}
A newly isolated strain, Proteus vulgaris OR34, from olive mill waste was found to secrete an alkaline extracellular lipase at $11 \mathrm{U} \cdot \mathrm{ml}^{-1}$ when cultivated on an optimized liquid medium. This lipase was purified 94.64fold with a total yield of $9.11 \%$ and its maximal specific activity was shown to be 3232.58 and $1777.92 \mathrm{U} \cdot \mathrm{mg}^{-1}$ when evaluated using the pH-stat technique at $55^{\circ} \mathrm{C}$ and $\mathrm{pH} 9$ and Tributyrin $\mathrm{TC} 4$ or olive oil as the substrate. The molecular mass of the pure OR34 lipase was estimated to be around $31 \mathrm{kDa}$, as revealed by SDSPAGE and its substrate specificity was investigated using a variety of triglycerides. This assay revealed that OR34 lipase preferred short and medium chain fatty acids. In addition, this lipase was stable in the presence of high concentrations of bile salt $(\mathrm{NaDC})$ and calcium ions appear not to be necessary for its activity. This lipase was inhibited by THL (Orlistat) which confirmed its identity as a serine enzyme. In addition, the immobilization of OR34 lipase by adsorption onto calcium carbonate increased its stability at higher temperatures and within a larger $\mathrm{pH}$ range. The immobilized lipase exhibited a high tolerance to organic solvents and retained $60 \%$ of its activity after 10 months of storage at $4{ }^{\circ} \mathrm{C}$. Finally, the OR34 lipase was applied in biodiesel synthesis via oleic acid mediated esterification of methanol when using hexane as solvent. The best conversion yield (67\%) was obtained at $12 \mathrm{~h}$ and $40{ }^{\circ} \mathrm{C}$ using the immobilized enzyme and this enzyme could be reused for six cycles with the same efficiency.
\end{abstract}

Keywords: Lipase, Proteus vulgaris, purification, immobilization, biodiesel

\section{Introduction}

Lipases (triacylglycerol acylhydrolases EC 3.1.1.3) are important hydrolytic enzymes, termed as carboxyl esterases, which can perform their catalytic activity in both aqueous and non aqueous media. They catalyze the hydrolysis of triacylglycerides to glycerol and free fatty acids in aqueous media. In addition, they catalyze the reverse reactions such as esterification, interesterification and transesterification in non aqueous conditions

\section{*Corresponding author}

Tel: +212620584937

E-mail: asmae.misbah@usmba.ac.ma

○ 2020, The Korean Society for Microbiology and Biotechnology
[1]. In contrast to esterases, lipases are activated only when adsorbed to an oil/water interface [2]. Lipases are ubiquitous in nature and can be produced by a variety of plants, animals and microorganisms [3]. However, microbial lipases are more suitable for biotechnological use due to their availability, high stability and wide substrate specificity [4]. They can be secreted by a large variety of microorganisms under defined culture conditions specific for each strain [5, 6]. Indeed, the environment where these microorganisms were isolated confers some characteristics to these enzymes [7, 8]. Due to these properties, microbial lipases are applied in several industrial applications, such as detergent formulations, biodiesel synthesis, production of pharmaceutical and 
cosmetic esters, food and treatment of wastewaters [9]. However, because of their biological origin, enzymes show some limitations like the complexity of their purification since they present the minimal portion of crude extract. Moreover, enzymes are soluble and unstable against some conditions like high temperatures, $\mathrm{pH}$, organic solvents and detergents [10, 11]. For these reasons, many of the functional and biochemical properties of microbial lipases need to be improved in order to increase their industrial implementation. Indeed, the immobilization is a technique which consists to the attachment of enzymes to solid support materials in order to improve their activity, stability and reusability for a continuous process [12]. Several studies reported the different lipases immobilization techniques such as physical adsorption [13], entrapment or microencapsulation [14, 15] and covalence binding to a solid matrix [16]. Among these techniques, adsorption may have the highest interest due to its relatively low cost and simplicity [17]. Among lipase-producing bacteria, Proteus genus was reported in literature. In fact, Kim et al. [18] isolated a Proteus vulgrais K80 strain from soil collected near a sewage disposal plant, which was able to produce an alkaline extracellular lipase. This lipase was immobilized on amine-terminated magnetic microparticles by covalence binding technique, in order to increase their functional properties [19]. In addition, Proteus sp. SW1 strain was reported to be able to produce a highly organic-solvent tolerant lipase, which was effective at converting palm oil into biodiesel [20]. Moreover, Proteus mirabilis lipase was shown to be a promising biocatalyst for biodiesel synthesis and their properties were improved using directed evolution [21].

Therefore, bacteria belonging to the Proteus genus were known as extracellular-alkaline lipase producers. However, the majority of studies reported lipases of Proteus genus produced from coding genes expression [20, 45, 48]. Also, reports on immobilization of Proteus lipases [19] and their application under native form are still limited.

In this context, we report in this paper the purification and the characterization of an extracellular alkaline and organic-solvent tolerant lipase, produced by Proteus vulgaris OR34 bacterial strain which was isolated previously from Moroccan olive mill wastes. Further- more, the pure lipase was immobilized by physical adsorption technique, onto carbonate calcium support for the first time, and compared to the soluble lipase. Finally, the immobilized OR34 lipase was tested for the synthesis of methyl oleate (biodiesel) by esterification reaction.

\section{Materials and Methods}

\section{Lipase production and extraction}

Proteus vulgaris OR34 (NCBI accession number: MN 622879) was previously isolated from Moroccan olive mill wastes [22] and routinely maintained on Luria-Bertani agar. The production of Proteus vulgaris OR34 lipase is ensured on a liquid medium previously described [22], which composed of $\left(\mathrm{g} \cdot \mathrm{l}^{-1}\right)$ : 15 casein peptone, 5 yeast extract, $5 \mathrm{NaCl}, 2.5$ glucose, $3 \mathrm{~K}_{2} \mathrm{HPO}_{4}$, $1 \mathrm{KH}_{2} \mathrm{PO}_{4}$, with a final $\mathrm{pH}$ of 7.4. After $30 \mathrm{~h}$ of incubation at $37^{\circ} \mathrm{C}$ and $180 \mathrm{rpm}$, the supernatant that contains the crude extracellular lipase, was recovered by centrifugation at $13,000 \mathrm{rpm}$ for $20 \mathrm{~min}$ at $4^{\circ} \mathrm{C}$.

\section{Lipase activity determination}

The lipase activity was measured titrimetrically at $\mathrm{pH}$ 9 and $55^{\circ} \mathrm{C}$ using $\mathrm{pH}$-stat technique (Switzerland), using olive oil emulsion $(10 \mathrm{ml})$ in $20 \mathrm{ml}$ of $2 \mathrm{mM}$ Tris- $\mathrm{HCl}$ buffer (150 mM NaCl, $2 \mathrm{mM} \mathrm{NaDC}$ and $3 \mathrm{mM} \mathrm{CaCl}_{2}$ ). The olive oil emulsion was obtained by mixing $10 \mathrm{ml}$ of olive oil in $90 \mathrm{ml}$ of $10 \%$ (w/v) Gum Arabic. Lipase activity was also measured using tributyrin TC4 (0.3 ml) as substrate in $30 \mathrm{ml}$ of $2 \mathrm{mM}$ Tris-HCl buffer. Other lipid substrates (sunflower oil, soybean oil, palm oil, peanut oil) were used following the same protocol as that of olive oil [23]. Synthetic substrates (Tricaprylin TC8, Trilaurin TC12, Tripalmitin TC16 and Triolein TC18) were used following the protocol established for TC4 [24]. The fatty acids released were titrated by adding sodium hydroxide $(0.1 \mathrm{~N})$ to the reaction medium. The enzymatic activity was expressed in International Units (1 IU corresponds to $1 \mu \mathrm{mol}$ of fatty acid released per $\min )$.

\section{Determination of protein concentration}

Protein concentration was determined as described by Bradford [25] using BSA as standard. 


\section{Procedure of OR34 lipase purification}

The culture supernatant $(1 \mathrm{~L})$ containing extracellular lipase was precipitated using solid ammonium sulfate at $65 \%$ saturation. After centrifugation (9500 rpm for $30 \mathrm{~min}$ at $4^{\circ} \mathrm{C}$ ), the pellet obtained was dissolved in a minimum of buffer A (50 mM Tris-HCl, pH 8, $20 \mathrm{mM}$ $\mathrm{NaCl}, 2 \mathrm{mM}$ benzamidine) and then centrifuged $\left(13,000 \mathrm{rpm}\right.$ for $5 \mathrm{~min}$ at $\left.4^{\circ} \mathrm{C}\right)$ to remove insoluble material. The supernatant obtained, containing the concentrated protein solution was applied to a Sephacryl S-100 column $(2.5 \times 150 \mathrm{~cm})$ previously equilibrated with buffer $\mathrm{A}$ at a rate of $30 \mathrm{ml} \cdot \mathrm{h}^{-1}$. The fractions containing lipase activity were pooled and deposited on a Mono-Q Sepharose column anion exchanger equilibrated with buffer $\mathrm{A}$. The column $(2 \times 30 \mathrm{~cm})$ was rinsed with $300 \mathrm{ml}$ of the same buffer. No lipase activity was detected in the washing flow and adsorbed material was eluted with a linear gradient of $\mathrm{NaCl}(20-500 \mathrm{mM})$ in the buffer (A) $(600 \mathrm{ml})$ at rate of $45 \mathrm{ml} \cdot \mathrm{h}^{-1}$. The active fractions were collected and concentrated to a volume of $1 \mathrm{ml}$ by ultra filtration technique using a centrifugal concentrator (Vivaspin $^{\circledR}$ ) containing a $10 \mathrm{kDa}$ membrane. The enzyme concentrate was deposited on a Sephadex G-75 column $(1.6 \times 110 \mathrm{~cm})$ previously equilibrated with buffer $\mathrm{A}$ at rate of $8 \mathrm{ml} \cdot \mathrm{h}^{-1}$. Then the active fractions were collected and concentrated again by the same ultra filtration technique.

\section{Analytical methods}

The purified lipase was analyzed by polyacrylamide gel (15\%) electrophoresis under denaturizing conditions in the presence of sodium dodecyl sulfate and $\beta$-mercaptoethanol (SDS-PAGE) according to the Laemmli method [26]. Non-denaturing or native PAGE (electrophoresis at $4{ }^{\circ} \mathrm{C}$ in the absence of SDS and $\beta$-mercaptoethanol) was performed using the discontinuous gel system of Ornstein [27] and Davis [28]. After electrophoresis, native gel was rinsed three times with buffer $\mathrm{A}$ containing 1\% Triton X-100. Next, Zymogram was accomplished on a solid revealing medium [29] containing: $30 \mathrm{ml}$ of buffer A, $0.3 \mathrm{ml}$ of TC4, $3 \mathrm{mM} \mathrm{CaCl}_{2}, 2 \mathrm{mM}$ $\mathrm{NaDC}, 1 \%(\mathrm{w} / \mathrm{v})$ agar-agar and $0.01 \%(\mathrm{w} / \mathrm{v})$ of phenol red as $\mathrm{pH}$ indicator. Finally, the incubation was performed at $55^{\circ} \mathrm{C}$ for $20 \mathrm{~min}$ and the lipase activity was revealed by the color deviation from red to yellow.

\section{Effect of bile salts, calcium ions and THL inhibitor on puri- fied lipase activity}

In order to study the bile salt effect on OR34 lipase activity, the hydrolysis of tributyrin by purified lipase was measured by the $\mathrm{pH}$-stat technique under standard conditions (the concentration of $\mathrm{Ca}^{2+}$ was fixed at $3 \mathrm{mM}$ ), in the presence of increasing concentrations of bile salts $\mathrm{NaDC}$ (1 to $10 \mathrm{mM})$.

To study the calcium dependence of the OR34 lipase, the activity was measured by the $\mathrm{pH}$-stat technique, using tributyrin under standard conditions (with $2 \mathrm{mM}$ $\mathrm{NaDC}$ ), in the presence of increasing calcium concentrations (from 1 to $10 \mathrm{mM}$ ). In the absence of calcium, the lipase activity was measured in the presence of $10 \mathrm{mM}$ EDTA which is a metalloenzyme inhibitor.

In order to confirm that OR34 lipase is a serine enzyme, the purified lipase was incubated with $0.1 \mathrm{mM}$ THL (Tetrahydrolipstatin $\mathrm{C}_{29} \mathrm{H}_{53} \mathrm{NO}_{5}$ : Orlistat), in both the presence and the absence of $4 \mathrm{mM} \mathrm{NaDC}$ [30], for one hour at room temperature. The residual lipase activity was measured after each $10 \mathrm{~min}$ by the $\mathrm{pH}$-stat technique using tributyrin substrate under standard conditions. A control containing the enzyme in the absence of THL was incubated under the same conditions.

\section{Immobilization of OR34 lipase}

The purified lipase was immobilized by adsorption on $\mathrm{CaCO}_{3}$ support according to the protocol described by Ghamgui et al. [31]. First, a volume of $1 \mathrm{ml}$ of pure enzyme (1002.1 IU) was added to $1 \mathrm{~g}$ of calcium carbonate, under stirring at $4^{\circ} \mathrm{C}$. The lipase adsorbed onto the support was washed with $20 \mathrm{ml}$ of acetone priory chilled at $-20^{\circ} \mathrm{C}$, and filtered on wattman paper. Finally, the immobilized enzyme was dried and stored at $4{ }^{\circ} \mathrm{C}$ until use. The immobilization yield ( $\mathrm{Ri}$ ) was measured at different incubation times ranging from $30 \mathrm{~min}$ to $3 \mathrm{~h}$, as the ratio of the adsorbed activity recovered at the end of the immobilization period divided by the total soluble lipase activity initially added to $1 \mathrm{~g}$ of the support.

\section{Characterization of free and immobilized OR34 lipase}

Effect of storage. The free and the immobilized lipases were stored at $4^{\circ} \mathrm{C}$ for 10 months. Samples were taken throughout the storage period and the residual activities 
were measured by the $\mathrm{pH}$-stat technique, using tributyrin, under standard conditions.

Effect of pH. The effect of $\mathrm{pH}$ on lipase activity was studied in the $\mathrm{pH}$ range varying from 4 to 11 using tributyrin at $55^{\circ} \mathrm{C}$. The effect of $\mathrm{pH}$ on lipase stability was determined by incubating the free and the immobilized lipases to different $\mathrm{pH}$ values varying from 4 to 11 for $1 \mathrm{~h}$ at $4^{\circ} \mathrm{C}$, using different buffers: Citrate buffer $(50 \mathrm{mM}$, pH: 4-5), phosphate buffer (50 mM, pH: 6-7), Tris-HCl buffer (50 mM, pH: 8-9) and Glycine- $\mathrm{NaOH}$ buffer (50 mM, pH: 10-11). Then the residual lipase activities were measured under standard conditions.

Effect of temperature. Effect of temperature on the free and the immobilized OR34 lipase activity was determined at $\mathrm{pH} 9$ in temperature range varying from 20 to $60^{\circ} \mathrm{C}$, using tributyrin as substrate. Relative activities were calculated as the ratio of the lipase activity measured at different temperatures to the maximal activity of the enzyme measured as described above.

The thermal stability assays were performed by incubation for $1 \mathrm{~h}$ of the immobilized or the free OR34 lipase at various temperatures $\left(20-80^{\circ} \mathrm{C}\right)$. After that, the residual activities were measured under standard conditions $\left(\mathrm{pH} 9,55^{\circ} \mathrm{C}\right)$ as the ratio of the activity measured after incubation to the maximal activity of the enzyme.

Effect of organic solvents. The immobilized OR34 lipase was incubated with different organic solvents at $50 \%(\mathrm{v} / \mathrm{v})$ concentration (DMSO, methanol, ethanol, iso-propanol, acetone, hexane and chloroform) for $24 \mathrm{~h}$ at $40^{\circ} \mathrm{C}$. Then the solvent was removed by centrifugation and the immobilized lipase was dried under vacuum. The residual activities were measured, using tributyrin under standard conditions, as the ratio of the activity of treated immobilized lipase to the activity of the untreated immobilized lipase.

\section{Esterification assay and reusability of OR34 immobilized lipase}

Esterification of oleic acid with methanol, catalyzed by the free and the immobilized lipase was tested according to some literature protocols [32-34]. The reaction was performed in screw-capped flask at $40^{\circ} \mathrm{C}$ and $150 \mathrm{rpm}$ for $24 \mathrm{~h}$. The reaction mixture was composed of: $500 \mathrm{U}$ of lipase (free or immobilized), $3 \mathrm{ml}$ of hexane and a molar ratio of 3:1 methanol/oleic acid. An enzyme-free control was carried out under the same conditions. Aliquots of $0.2 \mathrm{ml}$ were withdrawn every $4 \mathrm{~h}$ from the reaction mixture to determine the degree of conversion. Firstly, the enzyme was recovered by centrifugation at $13,000 \mathrm{rpm}$ for $5 \mathrm{~min}$ at $4^{\circ} \mathrm{C}$. Secondly, the supernatant was dissolved in $2 \mathrm{ml}$ of ethanol and the residual fatty acids were assayed by titration with $0.1 \mathrm{~N} \mathrm{NaOH}$ solution using phenophthalein as indicator colored. The degree of conversion (\%) was calculated as follows:

$$
\text { Conversion }(\%)=\frac{I A 1-I A 2}{I A 1} \times 100
$$

With: IA1: Acid Index before esterification IA2: Acid Index of the sample after esterification

The enzyme recovered by centrifugation at 13,000 rpm for $5 \mathrm{~min}$, after esterification reaction, was washed once with hexane in order to remove any substrate or product retained in the support. Then it was dried at room temperature for $1 \mathrm{~h}$ and reused again for another reaction cycle using fresh substrates. A total of 10 continuous esterification cycles using the same initial immobilized lipase were established and the degrees of conversion were calculated after each cycle.

\section{Results}

\section{Production of OR34 lipase}

The maximal lipase production was obtained after $30 \mathrm{~h}$ of culture incubation at $37^{\circ} \mathrm{C}$ under $180 \mathrm{rpm}$ shaking. The supernatant obtained after centrifugation of the culture broth at $13,000 \mathrm{rpm}$ for $20 \mathrm{~min}$ at $4^{\circ} \mathrm{C}$, showed a lipolytic activity of $11 \mathrm{U} \cdot \mathrm{ml}^{-1}$ on tributyrin and 5.7 $\mathrm{U} \cdot \mathrm{ml}^{-1}$ on olive oil emulsion as substrates, using $\mathrm{pH}$-stat technique under standard conditions.

\section{Purification of OR34 lipase}

The extracellular lipase produced by Proteus vulgaris OR34 was purified to homogeneity from the culture medium. The enzyme was precipitated with $65 \%$ saturation of ammonium sulfate and the precipitate was solubilized in buffer A and loaded to Sephacryl S-100 gel filtration column. The elution was performed with the same buffer (Fig. 1A). The active fractions were applied 

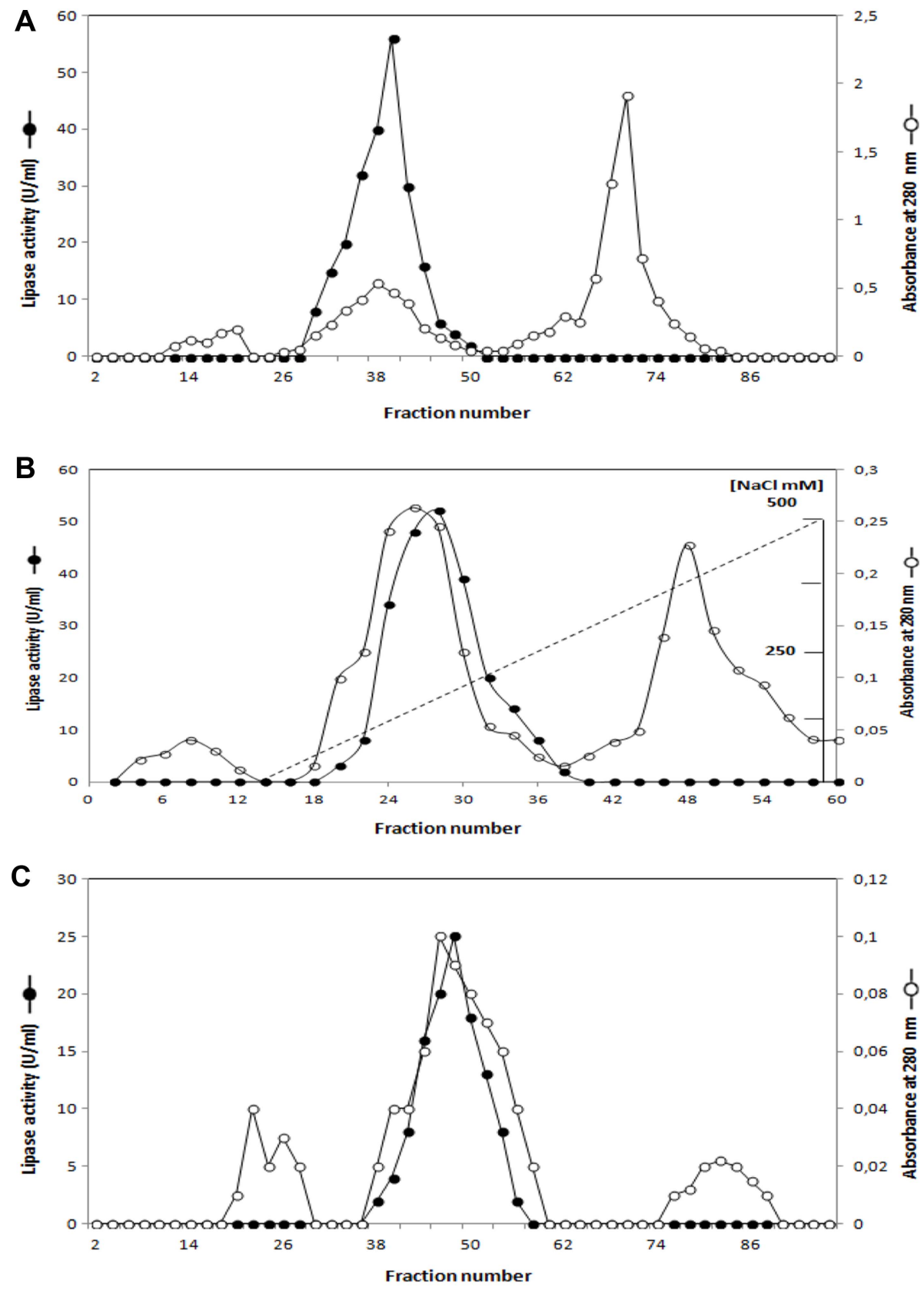

Fig. 1. Purification steps of OR34 lipase. (A) Chromatography on Sephacryl S-100. The column $(2.5 \times 150 \mathrm{~cm})$ was equilibrated with buffer A ( $50 \mathrm{mM}$ Tris- $\mathrm{HCl}, \mathrm{pH} 8,20 \mathrm{mM} \mathrm{NaCl}, 2 \mathrm{mM}$ benzamidine). Elution of proteins was performed with the same buffer at a rate of $30 \mathrm{ml} \cdot \mathrm{h}^{-1}$. (B) Chromatography on Mono-Q Sepharose. The column $(2 \times 30 \mathrm{~cm})$ was equilibrated with buffer $A$ and elution was performed with a linear gradient of $\mathrm{NaCl}(20-500 \mathrm{mM})$ at a rate of $45 \mathrm{ml} \cdot \mathrm{h}^{-1}$. (C) Chromatography on Sephadex G-75. The column $(1.6 \times 110 \mathrm{~cm})$ was equilibrated with buffer $A$. The elution was performed with the same buffer at rate of $8 \mathrm{ml} \cdot \mathrm{h}^{-1}$.

to a Mono-Q Sepharose chromatography. Unbound proteins were washed out with buffer A. Then the elution of adsorbed proteins was performed with a linear gradient of $\mathrm{NaCl}(20-500 \mathrm{mM})$. As shown in Fig. 1B, OR34 lipase was eluted between 100 and $220 \mathrm{mM}$. After that, the active fractions were concentrated using ultrafiltration technique (molecular weight cutoff of $10 \mathrm{kDa}$ ) and the concentrate was applied on a second gel filtration 
Table 1. Flow sheet of the purification procedure of OR34 lipase.

\begin{tabular}{lccccccc}
\hline \multicolumn{1}{c}{ Purification step } & $\begin{array}{c}\text { Lipase } \\
\text { activity } \\
\left(\mathrm{U} \cdot \mathrm{ml}^{-1}\right)\end{array}$ & $\begin{array}{c}\text { Volume } \\
(\mathrm{ml})\end{array}$ & $\begin{array}{c}\text { Total } \\
\text { activity } \\
(\text { Units })^{\mathrm{a}}\end{array}$ & $\begin{array}{c}\text { Proteins } \\
(\mathrm{mg})^{\mathrm{b}}\end{array}$ & $\begin{array}{c}\text { Specific } \\
\text { activity } \\
\left(\mathrm{U} \cdot \mathrm{mg}^{-1}\right)\end{array}$ & $\begin{array}{c}\text { Activity } \\
\text { recovery } \\
(\%)\end{array}$ & $\begin{array}{c}\text { Purification } \\
\text { factor }\end{array}$ \\
\hline Culture supernatant & 11 & 1000 & 11000 & 322 & 34.16 & 100 & 1 \\
$\left(\mathrm{NH}_{4}\right)_{2} \mathrm{SO}_{4}$ precipitation (65\%) & 715 & 10 & 7150 & 84 & 85.12 & 65 & 2.49 \\
Sephacryl S-100 chromatography & 73.33 & 60 & 4400 & 9.8 & 448.98 & 40 & 13.14 \\
Mono-Q Sepharose chromatography & 60.5 & 40 & 2420 & 1.9 & 1273.68 & 22 & 37.28 \\
Ultrafiltration & 2095.5 & 1 & 2095.5 & 0.72 & 2910.42 & 19.05 & 85.22 \\
Sephadex G-75 chromatography & 40.45 & 30 & 1213.3 & 0.4 & 3033.25 & 11.03 & 88.82 \\
Ultrafiltration & 1002.1 & 1 & 1002.1 & 0.31 & 3232.58 & 9.11 & 94.64 \\
\hline
\end{tabular}

anit: $1 \mu \mathrm{mol}$ of fatty acid released per minute using TC4 as substrate under standard conditions.

broteins were estimated by Bradford method.

Sephadex G-75. Proteins elution was performed with buffer $\mathrm{A}$ and the peak of lipase activity was detected in fraction 48 (Fig. 1C). A summary of the purification data is presented in Table 1 . The specific activity of the pure lipase reached 3232.58 and $1777.92 \mathrm{U} \cdot \mathrm{mg}^{-1}$ using TC4 and olive oil as substrates, respectively. The OR34 lipase was purified 94.64-fold with an overall recovery yield of $9.11 \%$ using TC4 as substrate.

\section{SDS-PAGE and Zymographic analysis}

The active fractions of the last step were pooled, concentrated and analyzed on 15\% SDS-PAGE using proteins standard. As shown in Fig. 2A, a single band

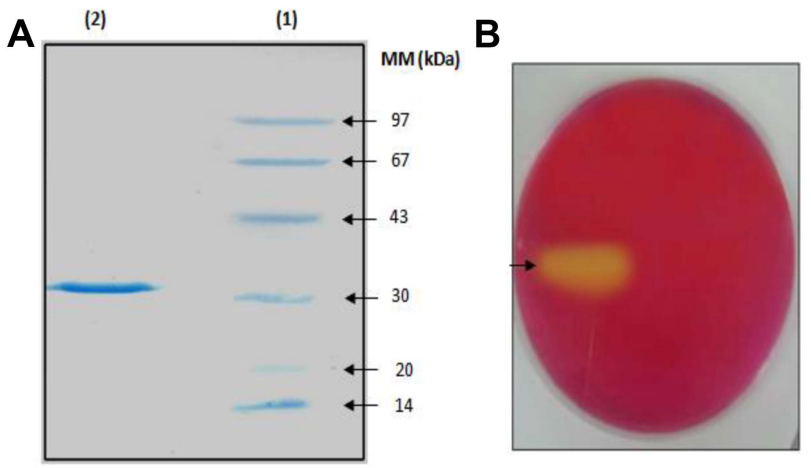

Fig. 2. SDS-PAGE and Zymography of the purified OR34 lipase. (A) SDS-PAGE (15\%) analysis of OR34 lipase. Lane 1: molecular mass markers (Pharmacia). Lane 2: purified OR34 lipase obtained after Mono-Q sepharose chromatography and ultrafiltration. (B) Zymogram demonstrating the OR34 lipase activity toward TC4. Native PAGE gel was incubated for $30 \mathrm{~min}$ at $55^{\circ} \mathrm{C}$. A positive lipolysis is showed by a deviation of red color to yellow using phenol red as $\mathrm{pH}$ indicator. with an apparent molecular weight of $31 \mathrm{kDa}$ was observed. The lipase activity of this homogeneous band was confirmed by Zymogram assay under non-denaturizing conditions. As shown in Fig. 2B, a positive lipolysis was revealed by the deviation of red color of phenol to yellow (pH indicator), due to hydrolysis of TC4 and liberation of free fatty acids.

\section{Substrates specificity of OR34 lipase}

The substrate specificity and chain length selectivity were determined by $\mathrm{pH}$-stat technique using a variety of triglycerides. The OR34 lipase was able to hydrolyze all natural lipid substrates tested (Fig. 3A). The highest activity (3119.16 $\left.\mathrm{U} \cdot \mathrm{mg}^{-1}\right)$, which was taken as $100 \%$, was shown against palm oil which has the highest saturated fatty acid content of the oils assayed. The enzyme can also hydrolyze peanut oil $\left(2183.41 \mathrm{U} \cdot \mathrm{mg}^{-1}\right)$ and soybean oil $\left(2058.65 \mathrm{U} \cdot \mathrm{mg}^{-1}\right)$ with relative activities of 70 and $66 \%$, respectively. The hydrolysis of olive oil (1777.92 $\left.\mathrm{U} \cdot \mathrm{mg}^{-1}\right)$ and sunflower oil $\left(1372.43 \mathrm{U} \cdot \mathrm{mg}^{-1}\right)$ achieved 57 and $44 \%$, respectively. With respect to the fatty acid specificity, OR34 lipase preferred triglycerides containing short and medium chain fatty acids (Fig. 3B). It showed the highest activity (3232.58 $\left.\mathrm{U} \cdot \mathrm{mg}^{-1}\right)$, which was taken as $100 \%$, towards Tributyrin TC4 followed by Tricaprylin TC8 (2844.67 U $\left.\cdot \mathrm{mg}^{-1} / 88 \%\right)$ and Trilaurin TC12 (2359.78 U $\left.\cdot \mathrm{mg}^{-1} / 73 \%\right)$. However the triglycerides with long acyl chain lengths like Tripalmitin TC16 (1131.4 U $\left.\cdot \mathrm{mg}^{-1}\right)$ and Triolein TC18 (937.45 U $\left.\cdot \mathrm{mg}^{-1}\right)$ were less hydrolyzed with relative activities of 35 and $29 \%$, respectively. 

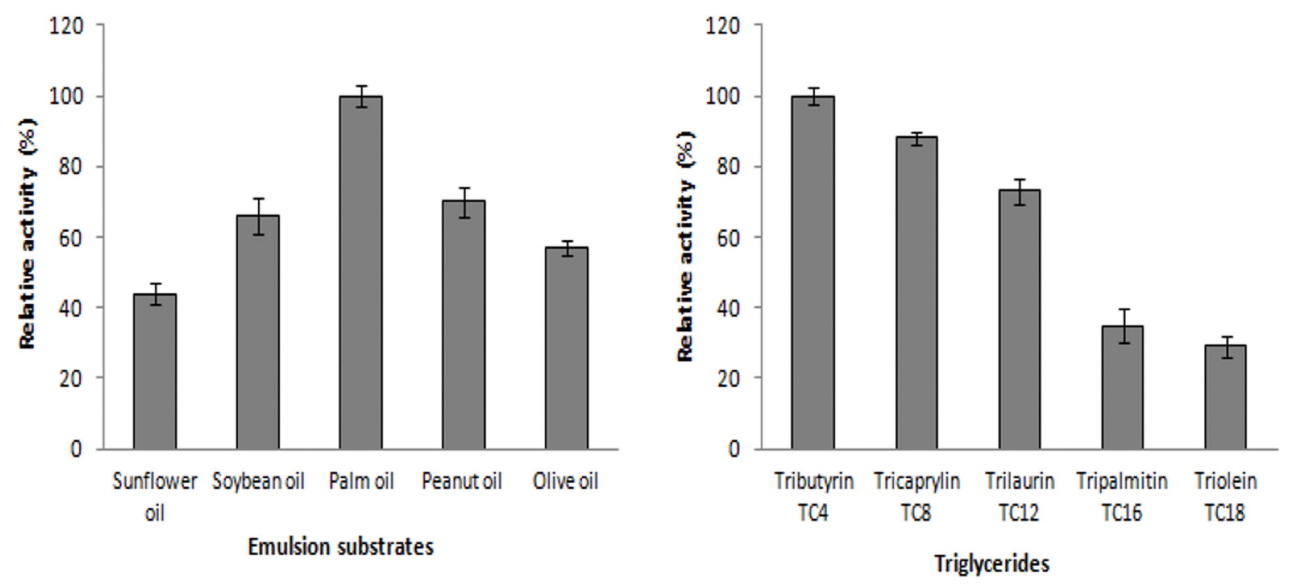

Fig. 3. Hydrolytic activities of OR34 lipase towards different substrates. (A) Substrate specificity of the lipase toward various emulsion oils. Lipase activities are expressed as the percentage of that of palm oil, which was taken as $100 \%$. (B) Substrate specificity of the lipase toward various triglycerides. Lipase activities are expressed as the percentage of that of Tributyrin, which was taken as $100 \%$. The results are the mean \pm S.D. of three separate experiments.
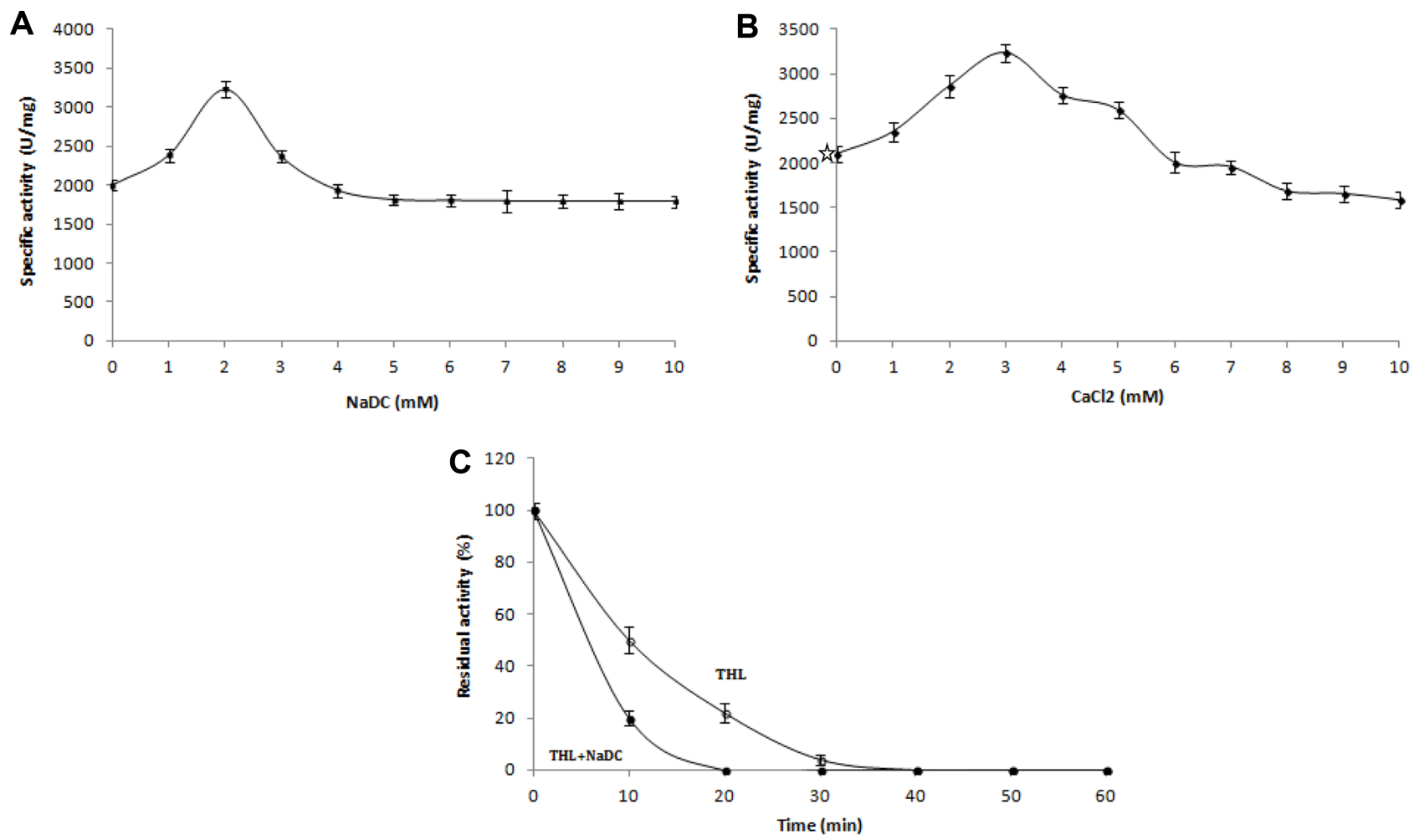

Fig. 4. Characterization of the purified OR34 lipase. (A) Effect of increasing concentration of bile salt (NaDC) on OR34 lipase activity in presence of $3 \mathrm{mM} \mathrm{CaCl}_{2}$ using Tributyrin TC4 as substrate under standard conditions. (B) Effect of increasing concentration of $\mathrm{CaCl}_{2}$ in presence of $2 \mathrm{mM} \mathrm{NaDC}$. The star indicates the lipase activity measured in the absence of $\mathrm{CaCl}_{2}$ and in the presence of 10 mM EDTA. (C) Effect of Orlistat on the OR34 lipase activity. The pure enzyme was incubated at room temperature with $0.1 \mathrm{mM}$ THL (either with or without $\mathrm{NaDC}$ ) and the residual activities were measured using Tributyrin TC4 under standard conditions. The results are the mean \pm S.D. of three separate experiments. 


\section{Effect of bile salts, calcium ions and THL inhibitor on puri- fied lipase activity}

In order to check if the purified OR34 lipase is able to hydrolyze triacylglycerols in the presence of surfaceactive agents like bile salts, the hydrolysis rate of TC4 was measured in the presence of increasing concentrations of $\mathrm{NaDC}$, under standard conditions. Fig. 4A showed that the specific activity of OR34 lipase reached the maximum $\left(3232.58 \mathrm{U} \cdot \mathrm{mg}^{-1}\right)$ at $2 \mathrm{mM} \mathrm{NaDC}$. This natural detergent has no inhibitory effect on the OR34 lipase $\left(1789 \mathrm{U} \cdot \mathrm{mg}^{-1}\right)$ even at a large concentration (10 mM).

Concerning the effect of $\mathrm{Ca}^{2+}$ ions, Fig. $4 \mathrm{~B}$ shows that calcium ions seems to be not necessary to trigger the OR34 lipase activity which can be detected $\left(2100 \mathrm{U} \cdot \mathrm{mg}^{-1}\right)$ in the absence of $\mathrm{Ca}^{2+}$ and the presence of $10 \mathrm{mM}$ EDTA as chelator. The specific activity of OR34 lipase reached its maximal $\left(3232.58 \mathrm{U} \cdot \mathrm{mg}^{-1}\right)$ at $3 \mathrm{mM}$ of $\mathrm{CaCl}_{2}$ and in the absence of chelator.

In order to check if the purified OR34 lipase is a serine enzyme, it was incubated with THL, either in the presence or in the absence of $\mathrm{NaDC}$, and the residual activities were measured under standard conditions using TC4 as substrate. Fig. 4C shows that after 30 min of incubation in the absence of NaDC, the OR34 lipase was totally inhibited. The addition of $4 \mathrm{mM}$ of $\mathrm{NaDC}$ in the medium accelerated the inactivation of the OR34 lipase which was reached at 20 min of incubation.

\section{Immobilization of OR34 lipase}

The immobilization yield ( $\mathrm{Ri}$ ) was measured at differ-

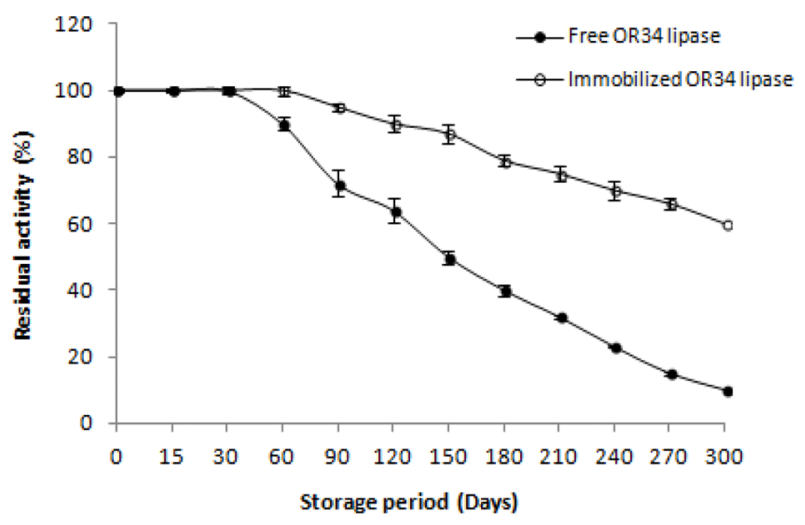

Fig. 5. Residual activity of the free and the immobilized OR34 lipase after storage period of 300 days at $4{ }^{\circ} \mathrm{C}$. The results are the mean \pm S.D. of three separate experiments. ent incubation times of enzyme (1002.1 IU) with $1 \mathrm{~g}$ of support $\left(\mathrm{CaCO}_{3}\right)$ at $4{ }^{\circ} \mathrm{C}$ under stirring. An incubation time of 60 min was ideal to reach the maximal adsorption of the OR34 lipase onto the support (901.89 IU), with the highest immobilization yield of $90 \%$ (data not shown).

\section{Characterization of free and immobilized OR34 lipase}

Effect of storage. The ability to be stored for certain period of time was investigated (Fig. 5). The immobilized OR34 lipase retained $100 \%$ of its initial activity (3232.58 $\mathrm{U} \cdot \mathrm{mg}^{-1}$ ) after a storage period of 60 days at $4{ }^{\circ} \mathrm{C}$, whereas the activity of the free lipase decreased to $90 \%$ (2909.32 $\mathrm{U} \cdot \mathrm{mg}^{-1}$ ) during the same period. Moreover the decrease of lipase activity over time was more accentuated in the case of the free lipase which retained only 10\% (323.252 $\mathrm{U} \cdot \mathrm{mg}^{-1}$ ) of its initial activity after 10 months, while the immobilized lipase maintained 60\% (1939.548 U $\cdot \mathrm{mg}^{-1}$ ) after the same period.
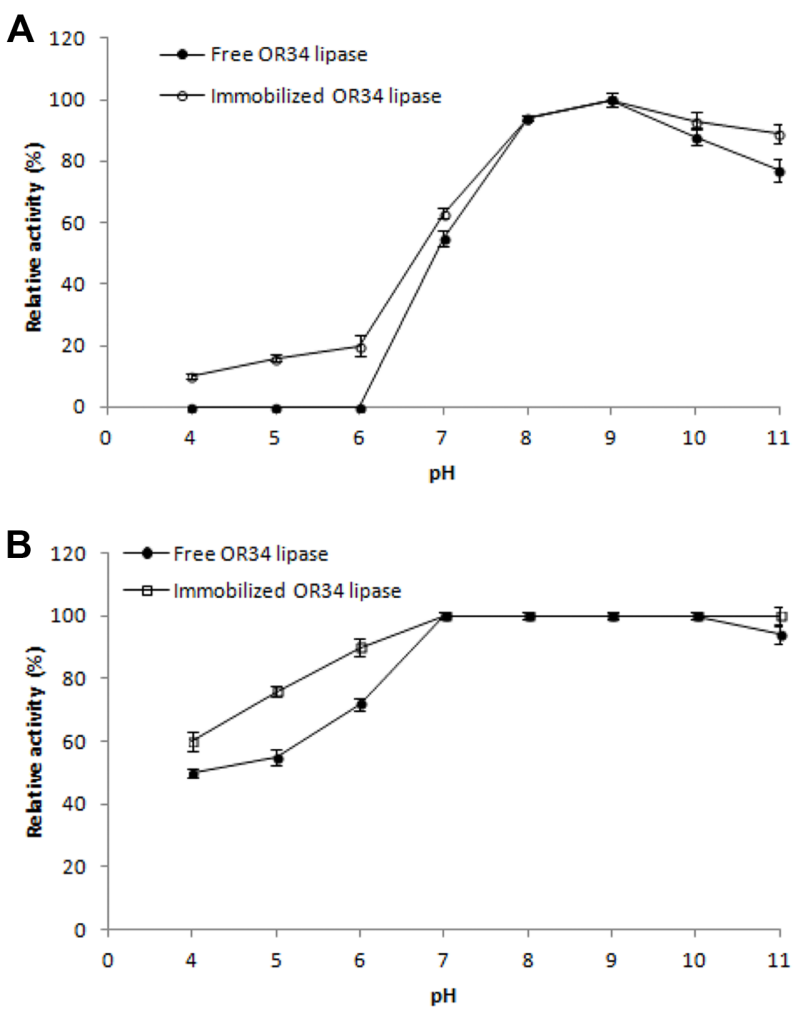

Fig. 6. Effect of pH on OR34 lipase activity (A) and stability (B) for both the free and the immobilized enzyme. Enzymes were incubated $1 \mathrm{~h}$ with different buffers at $4{ }^{\circ} \mathrm{C}$ for stability study. The results are the mean \pm S.D. of three separate experiments. 
Effect of pH. As shown in Fig. 6A, the immobilization has no effect on the optimal $\mathrm{pH}$ of activity. In fact, the highest activity $\left(3232.58 \mathrm{U} \cdot \mathrm{mg}^{-1}\right)$ for both free and immobilized OR34 lipase were obtained at pH 9. Moreover, the immobilized lipase presented between 10 and $20 \%$ of activity $\left(323-646 \mathrm{U} \cdot \mathrm{mg}^{-1}\right)$ at acid $\mathrm{pH}$ from 4 to 6 , while the free lipase was not active at these $\mathrm{pH}$ values. Concerning the $\mathrm{pH}$ stability, Fig. $6 \mathrm{~B}$ shows that the immobilized OR34 lipase remained stable and kept $100 \%$ of its activity $\left(3232.58 \mathrm{U} \cdot \mathrm{mg}^{-1}\right)$ within a large range of $\mathrm{pH}$ varying from 7 to 11 , while the free OR34 lipase retained about $94 \%$ of its activity (3038.62 $\mathrm{U} \cdot \mathrm{mg}^{-1}$ ) at $\mathrm{pH}$ 11. Moreover, the immobilized lipase was more stable than the free one at acid $\mathrm{pH}$. It retained between 60 and $90 \%$ of its activity (1939-2909 $\left.\mathrm{U} \cdot \mathrm{mg}^{-1}\right)$ at $\mathrm{pH}$ varying from 4 to 6 , while the free OR34 lipase maintained between 50 and $72 \%$ of its activity (1616-2327 $\mathrm{U} \cdot \mathrm{mg}^{-1}$ ) at the same $\mathrm{pH}$ range.
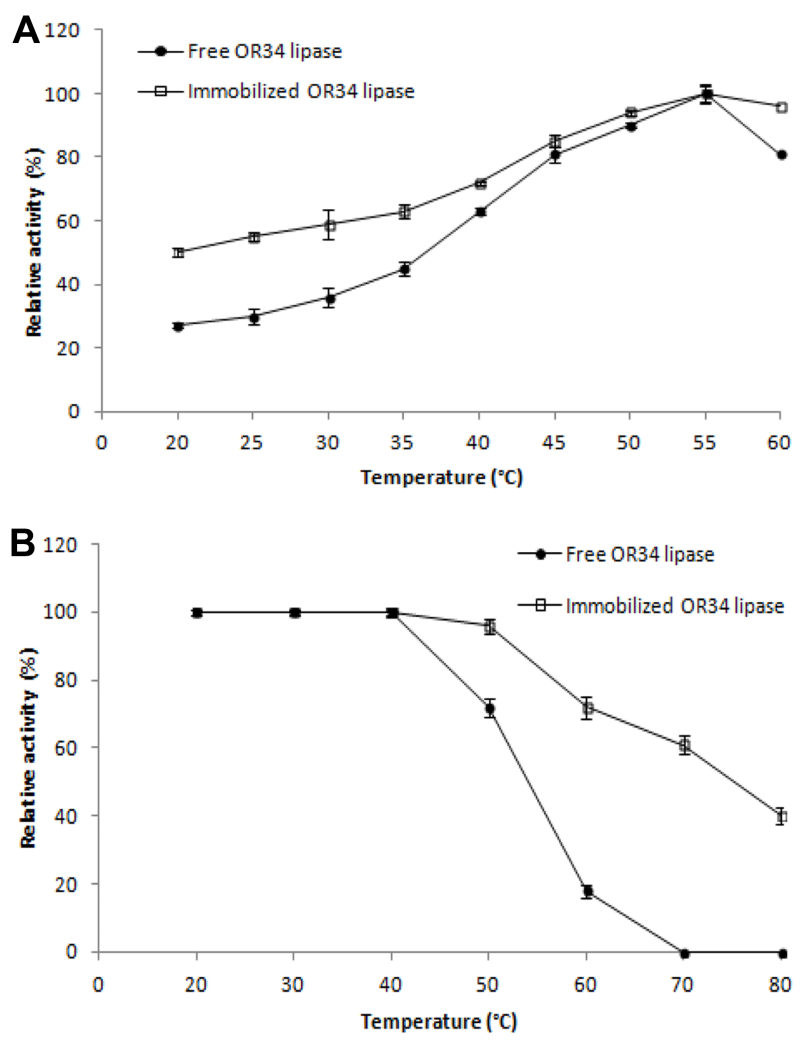

Fig. 7. Effect of temperature on OR34 lipase activity (A) and stability (B) for both the free and the immobilized enzyme. Enzymes were incubated $1 \mathrm{~h}$ at different temperatures for stability study. The results are the mean \pm S.D. of three separate experiments.
Effect of temperature. The activity profiles of the free and the immobilized OR34 lipase at different temperatures are presented in Fig. 7A. The optimal temperature for both free and immobilized lipase $\left(3232.58 \mathrm{U} \cdot \mathrm{mg}^{-1}\right)$ was found at $55^{\circ} \mathrm{C}$. However, the relative activity of the free lipase decreased to $81 \%\left(2618.39 \mathrm{U} \cdot \mathrm{mg}^{-1}\right)$ at $60^{\circ} \mathrm{C}$, while the immobilized lipase was more active and showed $96 \%$ of activity $\left(3103.28 \mathrm{U} \cdot \mathrm{mg}^{-1}\right)$ at the same temperature. In addition, the immobilized lipase was more active at low temperatures; it can show more than $50 \%$ of its initial activity $\left(1680 \mathrm{U} \cdot \mathrm{mg}^{-1}\right)$ at $20^{\circ} \mathrm{C}$ contrary to the free lipase which presents only $27 \%\left(872.8 \mathrm{U} \cdot \mathrm{mg}^{-1}\right)$ at this temperature. Concerning the thermostability, as shown in Fig. 7B the immobilized OR34 lipase was more stable at large range of temperatures. It retained 61 and $40 \%$ of its initial activity, which correspond to 1971.87 and $1293 \mathrm{U} \cdot \mathrm{mg}^{-1}$ at 70 and $80^{\circ} \mathrm{C}$, respectively, while the free lipase was totally inhibited at these temperatures.

Effect of organic solvents. The tolerance of immobilized OR34 lipase to organic solvents (polar and non-polar) was studied and the results are presented in Fig. 8. As it can be shown, the immobilized OR34 lipase was highly stable in the presence of $50 \%(\mathrm{v} / \mathrm{v})$ hexane; it retained more than $90 \%$ of its initial activity till $24 \mathrm{~h}$ of incubation at $40^{\circ} \mathrm{C}$. Moreover, it maintained more than $80 \%$ after $24 \mathrm{~h}$ of incubation at $40^{\circ} \mathrm{C}$, either with ethanol or

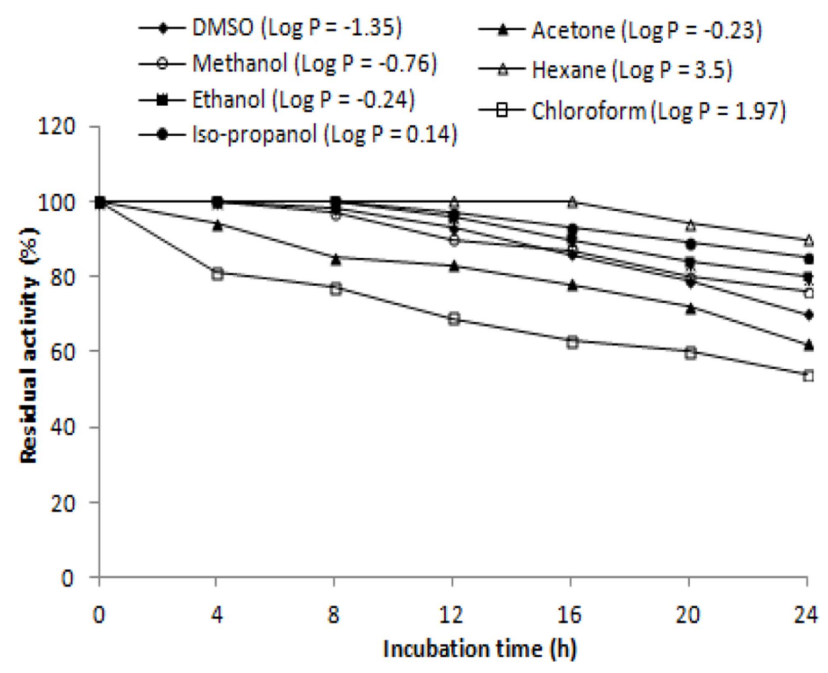

Fig. 8. Effect of different organic solvents at $\mathbf{5 0 \%}(\mathrm{v} / \mathrm{v})$ concentration on the stability of immobilized OR34 lipase. The residual activities were calculated after $24 \mathrm{~h}$ of incubation at $40{ }^{\circ} \mathrm{C}$. 

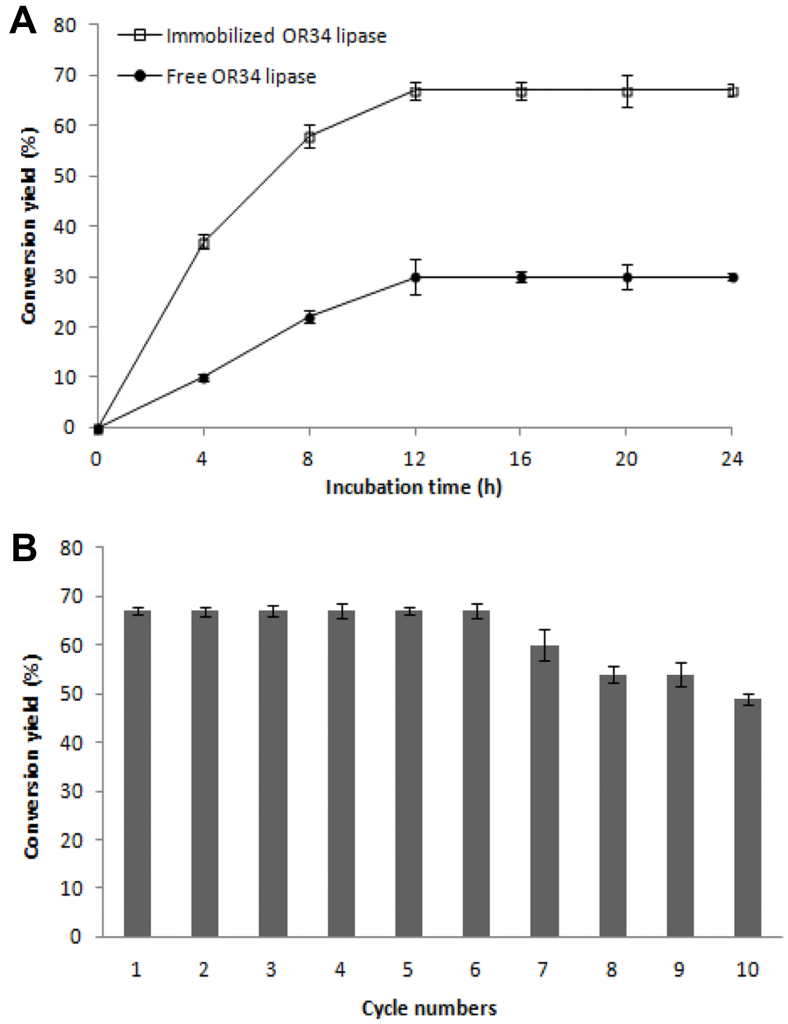

Fig. 9. Esterification reaction and reusability of the immobilized OR34 lipase. (A) Synthesis of methanol oleate by the free and the immobilized OR34 lipase. Esterification reaction was conducted at $40{ }^{\circ} \mathrm{C}$ and $150 \mathrm{rpm}$ for $24 \mathrm{~h}$ using $500 \mathrm{U}$ of enzyme in $3 \mathrm{ml}$ of hexane and methanol/oleic acid with molar ratio of 3:1. (B) Effect of reusability of immobilized OR34 lipase on the conversion yield. The incubation time was $12 \mathrm{~h}$ for each cycle. The results are the mean \pm S.D. of three separate experiments.

iso-propanol at $50 \%(\mathrm{v} / \mathrm{v})$. In the presence of methanol or DMSO the OR34 lipase conserved more than 70\% of its activity, while it lost about 46 or $38 \%$ of its activity when incubated with chloroform and acetone, respectively.

\section{Esterification reaction catalyzed by OR34 lipase}

After immobilization of OR34 lipase, its ability to catalyze esters synthesis in organic media was studied. The synthesis of methyl oleate (biodiesel) by direct esterification of methanol and oleic acid in hexane was taken as a reaction model and the conversion yield (\%) is calculated.

Kinetic synthesis. As seen in Fig. 9A, the highest conversion yield (67\%) was obtained with the immobi- lized OR34 lipase after $12 \mathrm{~h}$ of incubation at $40^{\circ} \mathrm{C}$, whereas the free lipase allowed only $30 \%$ of conversion at the same conditions.

Reusability. As shown in Fig. 9B, the immobilized OR34 lipase was reused 6 times with the same efficiency (conversion yield of 67\%). After 6 cycles the conversion starts to decrease and it reduced to approximately $49 \%$ after 10 successive cycles.

\section{Discussion}

Diverse lipases from many bacterial genera have been isolated and studied, such as Pseudomonas [35, 36], Serratia [37, 38], Staphylococcus [39, 40], Bacillus [41, 42] and Halomonas [43, 44]. Few lipases from Proteus genus were also reported in the literature, like those produced by Proteus vulgaris K80 [18], Proteus sp. SW1 [20], Proteus sp. K107 [45] and Proteus mirabilis [46]. Bacterial lipases are classified into 19 families based on amino acid sequences and biochemical characteristics [47]. The sequences of Proteus lipases reported share a high similarity with lipases from Pseudomonas fragi which were classified together as a separate sub-family in group I.1. They differ from other group I.1 lipases in their mechanism of secretion: they lack leader peptides, absence of two conserved Cys residues believed to be involved in disulfide bond formation, and they don't require the participation of a chaperone [18, 20, 45]. The crystal structure of lipase from Proteus mirabilis was solved and provides the first and unique structure of a lipase from the Proteus I.1 sub-family. It closely resembles the structure of the family I.1 (Pseudomonas aeruginosa), as well as family I.2 lipases (Burkholderia gluma and Burkholderia cepacia) with some unique features [46]. In this study, the purification of Proteus vulgaris OR34 lipase process resulted in 94.64-fold purification factor and a final recovery of $9.11 \%$ of the enzyme with specific activity of $3103.28 \mathrm{U} \cdot \mathrm{mg}^{-1}$. Kim et al. [18], purified a native lipase from Proteus vulgaris K80 strain, 300-fold with a yield of $25 \%$ and a final specific activity of 2000 $\mathrm{U} \cdot \mathrm{mg}^{-1}$. In addition, the pure OR34 lipase showed a single band by SDS-PAGE with a molecular mass estimated to be $31 \mathrm{kDa}$ which is similar to lipases from Proteus genus [18, 20, 45]. The OR34 lipase was able to hydrolyze a large range of oil substrates, with a prefer- 
ence to palm oil. Among the triglycerides tested (C4C18), it showed high activity against short and medium chain fatty acids esters. Indeed, the lipase from Proteus vulgaris K80 showed the highest activity against Tricaprylin (TC8) among the triglycerides tested (C4C16) [18], while lipase from Proteus sp. SW1 was more active against $p$-nitrophenyl laurate ( $p \mathrm{NL}, \mathrm{C} 12)$ among the synthetic esters tested (C2-C18) [20]. It has been reported that calcium ions are needed for lipolytic activity of some bacterial lipases. In fact, Liu et al. [50] demonstrated that lipase from Pseudomonas fluorescens Pf0-1, which belongs to sub-family I.1, was stimulated $(160 \%)$ in the presence of $10 \mathrm{mM} \mathrm{CaCl}_{2}$. Moreover, the activity of lipase from Staphylococcus hyicus (subfamilyI.6) increased about 40-fold in the presence of $\mathrm{Ca}^{2+}$ ions and was strongly inhibited in the presence of chelators [51]. Therefore, calcium ions might carry out three distinct roles in lipase action: removal of fatty acids as insoluble $\mathrm{Ca}^{2+}$ salts [52, 53], direct activation resulting from concentration of the enzyme at the lipid/ water interface [54] and structure stabilizing effect of the enzyme [55]. In this study, calcium seems to be not necessary to trigger the OR34 lipase activity that was detected $\left(2100 \mathrm{U} \cdot \mathrm{mg}^{-1}\right)$ even in the presence of $10 \mathrm{mM}$ EDTA. However, in the presence of $3 \mathrm{mM} \mathrm{CaCl}_{2}$ the OR34 lipase activity increased to $3232.58 \mathrm{U} \cdot \mathrm{mg}^{-1}$ suggesting that the enzyme is partially calcium dependent. In fact, lipases belonging to sub-family I.1 have a conserved $\mathrm{Ca}^{2+}$ binding located near the end of a 8 proposed to play a role in catalysis and stability [55, 57]. Since surfactants are important and frequently used in the preparation of emulsions for lipases assays, the effect of $\mathrm{NaDC}$ on OR34 lipase was studied in this work. It is reported that bile salts at concentrations above $2 \mathrm{mM}$ reversibly inhibited the hydrolyisis of Triolein by pancreatic lipase [58]. Several different mechanisms have been suggested to explain the bile salt inhibition: 1) the building of a detergent monolayer on the substrate surface that is negatively charged and that electrostatic repulsion is of importance. 2) A competition between lipase and bile salt for the interface and/or a lowering of the interfacial tension hindering lipase adsorption to the lipid/water interface. 3) The bile salts react cooperatively with lipase to form a complex with a negligible activity for the substrate [59]. In our case, NaDC has no inhibitory effect on OR34 lipase activity even at large concen- tration $(10 \mathrm{mM})$. Comparable results were obtained with lipase from Pseudomonas aeruginosa SRT 9, which retained $97.5 \%$ of its activity after incubation of $1 \mathrm{~h}$ with $\mathrm{NaDC}$ at $10 \%(\mathrm{w} / \mathrm{v})$ [60]. Our result shows that OR34 lipase has a penetrating power allowing it to access the lipid/water interfaces even in the presence of high concentrations of bile salts. Moreover, OR34 lipase reached its maximal activity in the presence of $2 \mathrm{mM} \mathrm{NaDC}$. This can be explained by the fact that bile salts at low concentrations $\left(\leq \mathrm{CMC}_{\mathrm{NaDC}}\right.$, critical micelle concentration of $\mathrm{NaDC}$ ), due to their hydrophobicity, stimulate lipase activity by inducing the opening of the lid and the fixation of enzyme at interface [61]. Tetrahydrolipstatin (THL, Orlistat) is a hydrogenated analogue of lipstatin produced by Streptomyces toxytricini, and is a potent inhibitor of gastrointestinal lipases. It has been suggested that a stoichiometric enzyme-inhibitor complex of a long lived acyl-enzyme type is formed between the $\beta$ lactone ring of THL and the hydroxyl group of the catalytic serine (ser 152) of pancreatic lipase [62, 63]. In this work, the inhibition of purified OR34 lipase by THL indicates that this lipase, like all the known lipases from different origins [67-69], is a serine enzyme. The THL inhibitor effect on OR34 lipase activity was enhanced in the presence of $\mathrm{NaDC}$, which is in accordance of the results founded by Salah et al. [68] and Zouari et al. [69]. In fact, it has been demonstrated that bile salts micelles are important in forming and stabilizing the THL-lipase complex, which accelerates the enzymatic inhibition [70]. After purification and characterization of OR34 lipase, the immobilization of the pure enzyme was performed by adsorption onto carbonate calcium support. The maximal adsorption (90\%) was reached after $60 \mathrm{~min}$, which correspond to the point of dynamic balance between adsorption and desorption. This is in accordance with the results showed for lipase from Rhizopus oryzae (ROL), which was immobilized by physical adsorption onto $\mathrm{CaCO}_{3}$ and presented a yield more than 95\% during $30 \mathrm{~min}$ [33]. Minovska et al. [71] reported that the same support displayed a similar immobilization yield (92\%) after $60 \mathrm{~min}$ of incubation, using the commercial Candida rugosa type VII lipase. However, the adsorption of Pseudomonas sp. KWI 56 lipase on the same support showed an immobilization yield of only $57.8 \%$ after 60 min of incubation [72]. In fact, $\mathrm{CaCO}_{3}$ appeared as a powder with small crystalline particles to 
produce a large adsorption surface area [33, 72]. In addition to its low cost, the $\mathrm{CaCO}_{3}$ has several advantages for use as a matrix including its lack of both toxicity and chemical reactivity with the enzyme [31, 33]. In this work, we showed that the immobilized OR34 lipase was more stable than the soluble lipase when stored at $4^{\circ} \mathrm{C}$. The immobilization of lipases to a support often limits their drastic conformational changes, and hence results in increased stability towards denaturation [33, 73, 74]. The maximal lipase activity for both the immobilized and the soluble enzyme was obtained at $\mathrm{pH} 9$ that consistent with other lipases from Proteus genus [18, 20, 45], while the immobilized enzyme showed an activity in a broader $\mathrm{pH}$ range. This result corroborate with that obtained by Kharrat et al. [73] who reported that the immobilization of ROL onto silica aerogels significantly improved the $\mathrm{pH}$ range of activity. The OR34 lipase activity detected at acidic $\mathrm{pH}$ after immobilization of the enzyme is in agreement of the result reported by Ghamgui et al. [33], who showed that immobilization of the ROL on $\mathrm{CaCO}_{3}$ support induce the activity at acidic $\mathrm{pH}$ values. We noted also an improvement of $\mathrm{pH}$ stability of OR34 lipase after immobilization, which can be explained by a multipoint covalent attachment of enzymes on the support [33]. This attachment maintained unaltered under mild denaturing environment (extreme $\mathrm{pH}$ values...), which induced the rigidity of the protein structure leading to its stability [75, 76]. Concerning the effect of temperature on OR34 lipase activity, both the immobilized and soluble enzymes were extremely active at $55^{\circ} \mathrm{C}$. A similar result was presented by other lipases from Proteus genus [18, 20], whereas Gao et al. [45] reported that $35^{\circ} \mathrm{C}$ was the optimal temperature for Proteus sp. K107 lipase activity. In this work, the immobilization of OR34 lipase increased the activity in a broader temperature range and improved the stability at high temperature values. It is often found that immobilized enzyme has a higher thermal stability than free enzyme due to restriction of its conformational flexibility attributed to its multiple attachment points on the support which limit the conformational alterations and movements under various temperatures [33, 73]. In this study the biodiesel synthesis via interesterification reaction was investigated. In fact, the immobilized lipases as biocatalysts have recently drawn great attention due to their environmental benefit, economic perspective and simpler operation over conventional chemical catalytic processes [77, 78]. The enzymatic reaction can be performed in the presence of organic solvents in order to increase the solubility of the substrates, reduce the viscosity of the reaction mixture and enhance the reaction rate. However, most organic solvents are toxic and denature the enzyme activity [79]. For this reason the stability of OR34 lipase in the presence of different organic solvents was studied. The results showed that the immobilized OR34 lipase was stable and retained more than $50 \%$ of its activity after $24 \mathrm{~h}$ of incubation in the presence of $50 \%(\mathrm{v} / \mathrm{v})$ of various organic solvents (hexane, ethanol, iso-propanol, DMSO, chloroform and acetone). These results are in accordance with those founded by Whangsuk et al. [20] who reported that Proteus sp. SW1 Lipase was highly stable in organic solvents (acetone, ethanol, hexane and isopropanol). In addition, Kharrat et al. [73] showed that silica aerogels-immobilized ROL was stable in the presence of various organic solvent especially the hydrophobic ones. Generally, it was found that the biodiesel production rate increases with the increase in the hydrophobicity of the solvent used [80]. Using hydrophilic solvents resulted in much lower rates due to their tendency to strip-off the bound water from the enzyme surface, resulting in the loss of the favorable structure and a decrease in the activity [81]. The activity of enzyme was correlated against solvent polarity and the stripping of water was found to occur when the hydrophobicity $(\log \mathrm{P})$ of the organic solvent was less than 2 , whereas the effect was not observed if the value was between 2 and 4 [79, 80]. That is why n-hexane, which has $\log \mathrm{P}=3.5$, has been commonly used, as a reaction medium, and its positive effect was proven in most biodiesel production studies [32, 82, 83]. In this work, the synthesis of methyl oleate was also performed in the presence of hexane and the maximal conversion yield obtained was about $67 \%$. Lipase from Proteus sp. W1 expressed in E. coli was used to catalyze the transesterification reaction of palm oil with ethanol to synthesis biodiesel and the conversion yield obtained was $43 \%$ [20]. However, the transesterification of rapeseed oil with methanol, catalyzed by lipase from Proteus sp. K107 (recombinant $E$. coli whole-cell) showed a conversion yield of $97 \%$ [45]. Furthermore, direct evolution was used to improve the organic solvents-tolerance and the thermal stability of lipase from Proteus mirbilis for bio- 
diesel production [21]. Finally, the immobilized OR34 lipase prepared in this study was reused for six cycles with the same efficiency. Natalia et al. [19] reported the immobilization of lipase from Proteus vulgaris K80 expressed in $E$. coli cells, onto amine-terminated magnetic microparticles (Mag-MPs). They found that the immobilized lipase was more active and stable at different $\mathrm{pH}$ and temperature values, had broader substrate specificity compared with the soluble lipase, and showed about $75 \%$ residual relative activity after six recovery trials.

It is the first time we report the immobilization of lipase from Proteus genus onto $\mathrm{CaCO}_{3}$ support and its application under native and immobilized form in biodiesel synthesis. These findings justify further studies to optimize the parameters of biodiesel esterification reaction.

\section{Acknowledgments}

This study was supported by "Ministry of Higher Education and Scientific research of Morocco".

\section{Conflict of Interest}

The authors have no financial conflicts of interest to declare.

\section{References}

1. Patel MT, Nagarajan R, Kilara A. 1996. Lipase-catalyzed biochemical reactions in novel media: A review. Chem. Eng. Commun. 152 : 365-404.

2. Reis $\mathrm{P}$, Holmberg K, Watzke H, Leser ME, Miller R. 2009. Lipases at interfaces: a review. Adv. Colloid Interf. Sci. 147: 237-250.

3. Pahoja VM, Sethar MA. 2002. A review of enzymatic properties of lipase in plants, animals and microorganisms. J. Appl. Sci. 2: 474484.

4. Agobo KU, Arazu VA, Uzo K, Igwe CN. 2017. Microbial lipases: a prospect for biotechnological industrial catalysis for green products: a review. J. Ferment. Technol. 6: 1-12.

5. Thakur S. 2012. Lipases, its sources, properties and applications: a review. Int. J. Sci. Eng. Res. 3: 1-29.

6. Treichel H, de Oliveira D, Mazutti MA, Di Luccio M, Oliveira JV. 2010. A review on microbial lipases production. Food. Bioprocess. Tech. 3: 182-196.

7. Ji X, Chen G, Zhang Q, Lin L, Wei Y. 2015. Purification and characterization of an extracellular cold-adapted alkaline lipase produced by psychrotrophic bacterium Yersinia enterocolitica strain KM1. J. Basic. Microbial. 55: 718-728.
8. Shao H, Xu L, Yan Y. 2014. Thermostable lipases from extremely radioresistant bacterium Deinococcus radiodurans: cloning, expression, and biochemical characterization J. Basic. Microbiol. 54: $984-995$.

9. Melani NB, Tambourgi EB, Silveira E. 2020. Lipases: From production to applications. Sep. Purif. Rev. 49: 143-158.

10. Robinson PK. 2015. Enzymes: principles and biotechnological applications. Ess. Biochem. 59: 1-41.

11. Javed S, Azeem F, Hussain S, Rasul I, Siddique MH, Riaz M, et al. 2018. Bacterial lipases: A review on purification and characterization. Prog. Biophys. Mol. Bio. 132: 23-34.

12. Nisha S, Karthick SA, Gobi N. 2012. A review on methods, application and properties of immobilized enzyme. Chem. Sci. Rev. Lett. 1: 148-155.

13. Khan AK, Mubarak NM, Abdullah EC, Khalid M, Nizamuddin S, Baloch HA, et al. 2019. Immobilization of Lipase Enzyme Carbon Nanotubes via Adsorption. IOP Conf. Ser. Mater. Sci. Eng. 495: 012055.

14. Pereira DS, Fraga JL, Diniz MM, Fontes-Sant'Ana GC, Amaral PFF 2018. High catalytic activity of lipase from Yarrowia lipolytica immobilized by microencapsulation. Int. J. Mol. Sci. 19: 3393.

15. Bhushan I, Parshad R, Qazi GN, Gupta VK. 2008. Immobilization of lipase by entrapment in Ca-alginate beads. J. Bioact. Compat. Pol. 23: 552-562.

16. Carvalho NB, Vidal BT, Barbosa AS, Pereira MM, Mattedi S, Freitas LDS, et al. 2018. Lipase immobilization on silica xerogel treated with protic ionic liquid and its application in biodiesel production from different oils. Int. J. Mol. Sci. 19: 1829.

17. Adlercreutz P. 2013. Immobilization and application of lipases in organic media. Chem. Soc. Rev. 42: 6406-6436.

18. Kim HK, Lee JK, Kim H, Oh TK. 1996. Characterization of an alkaline lipase from Proteus vulgaris K80 and the DNA sequence of the encoding gene. FEMS Microbiol. Lett. 135: 117-121.

19. Natalia A, Kristiani L, Kim HK. 2014. Characterization of Proteus vulgaris $\mathrm{k} 80$ lipase immobilized on amine-terminated magnetic microparticles. J. Microbiol. Biotechnol. 24: 1382-1388.

20. Whangsuk $W$, Sungkeeree $P$, Thiengmag $S$, Kerdwong J, Sallabhan R, Mongkolsuk S, 2013. Gene cloning and characterization of a novel highly organic solvent tolerant lipase from Proteus sp. SW1 and its application for biodiesel production. Mol. Biotechnol. 53: 55-62.

21. Korman TP, Sahachartsiri B, Charbonneau DM, Huang GL, Beauregard M, Bowie JU. 2013. Dieselzymes: development of a stable and methanol tolerant lipase for biodiesel production by directed evolution. Biotechnol. Biofuels 6: 70.

22. Misbah A, Aouine M, Er raouan S, Lekbach Y, Ettadili $H$, Ibnsouda Koraichi S, et al. 2019. Microorganisms isolated from Moroccan olive-mill wastes: Screening of their enzymatic activities for biotechnological use. Eur. Sci. J. 15: 464-494.

23. Rathelot J, Julien R, Canioni P, Coeroli C, Sarda L. 1976. Studies on the effect of bile salt and colipase on enzymatic lipolysis. Improved method for the determination of pancreatic lipase and colipase. Biochimie 57: 1117-1122. 
24. Gargouri Y, Pieroni G, Lowe PA, Sarda L, Verger R. 1986. Human gastric lipase. The effect of amphiphiles. Eur. J. Biochem. 156 : 305-310.

25. Bradford MM. 1976. A rapid and sensitive method for the quantitation of microgram quantities of protein utilizing the principle of protein-dye binding. Anal. Biochem. 72: 248-254.

26. Laemmli UK. 1970. Cleavage of structural proteins during the assembly of the head of bacteriophage T4. Nature 227: 680-685.

27. Ornstein L. 1964. Disc electrophoresis. I. Background and theory. Ann. NY Acad. Sci. 121: 321.

28. Davis BJ. 1964. Disc electrophoresis. II. Method and application to human serum proteins. Ann. NY Acad. Sci. 121: 404-427.

29. Singh R, Gupta N, Goswami VK, Gupta R. 2006. A simple activity staining protocol for lipases and esterases. Appl. Microbiol. Biotechnol. 70: 679-682.

30. Gargouri Y, Chahinian H, Moreau H, Ransac S, Verger R. 1991. Inactivation of pancreatic and gastric lipases by THL and C12: 0TNB: a kinetic study with emulsified tributyrin. Biochim. Biophys. Acta (BBA) - Lipids and Lipid Metabolism 1085: 322-328.

31. Ghamgui H, Karra chaabouni M, Gargouri Y. 2004. 1-Butyl oleate synthesis by immobilized lipase from Rhizopus oryzae: a comparative study between $\mathrm{n}$-hexane and solvent-free system. Enzyme. Microb. Technol. 35: 355-363.

32. Kaur M, Mehta A, Gupta R. 2019. Synthesis of methyl butyrate catalyzed by lipase from Aspergillus fumigatus. J. Oleo Sci. 68: 989993.

33. Ghamgui H, Miled N, Karra-chaâbouni M, Gargouri Y. 2007. Immobilization studies and biochemical properties of free and immobilized Rhizopus oryzae lipase onto $\mathrm{CaCO}_{3}$ : $\mathrm{A}$ comparative study. Biochem. Eng. J. 37: 34-41.

34. Deng L, Tan T, Wang F, Xu X. 2003. Enzymatic production of fatty acid alkyl esters with a lipase preparation from Candida sp. 99125. Eur. J. Lipid Sci. Technol. 105: 727-734.

35. Priyanka P, Kinsella G, Henehan GT, Ryan BJ. 2019. Isolation, purification and characterization of a novel solvent stable lipase from Pseudomonas reinekei. Protein Express. Purif. 153: 121-130.

36. Maraite A, Hoyos P, Carballeira JD, Cabrera ÁC, AnsorgeSchumacher MB, Alcántara AR. 2013. Lipase from Pseudomonas stutzeri: purification, homology modelling and rational explanation of the substrate binding mode. J. Mol. Catal B-Enzym. 87: 8898.

37. Mohammadi M, Sepehrizadeh Z, Ebrahim-Habibi A, Shahverdi AR, Faramarzi MA, Setayesh N. 2015. Bacterial expression and characterization of an active recombinant lipase $A$ from Serratia marcescens with truncated C-terminal region. J. Mol. Catal BEnzym. 120: 84-92.

38. Abdou AM. 2003. Purification and partial characterization of psychrotrophic Serratia marcescens lipase. J. Dairy. Sci. 86: 127-132.

39. Bouaziz A, Horchani H, Salem NB, Gargouri Y, Sayari A. 2011. Expression, purification of a novel alkaline Staphylococcus xylosus lipase acting at high temperature. Biochem. Eng. J. 54: 93-102.

40. Bacha AB, Al-Assaf A, Moubayed NM, Abid I. 2018. Evaluation of a novel thermo-alkaline Staphylococcus aureus lipase for applica- tion in detergent formulations. Saudi. J. Biol. Sci. 25: 409-417.

41. Oliveira AF, Bastos RG, Lucimara G. 2019. Bacillus subtilis immobilization in alginate microfluidic-based microparticles aiming to improve lipase productivity. Biochem. Eng. J. 143: 110-120.

42. Musa H, Kasim FH, Gunny AAN, Gopinath SC, Ahmad MA. 2018. Biosecretion of higher halophilic lipase by a novel Bacillus amyloliquefaciens AIKK2 using agro-waste as supporting substrate. Process. Biochem. 72: 55-62.

43. Jadhav VV, Pote SS, Yadav A, Shouche YS, Bhadekar RK. 2013. Extracellular cold active lipase from the psychrotrophic Halomonas sp. BRI 8 isolated from the Antarctic sea water. Songklanakarin J. Sci. Technol. 35: 623-630.

44. Gutiérrez-Arnillas E, Arellano M, Deive FJ, Rodríguez A, Sanromán MÁ. 2017. Unravelling the suitability of biological induction for halophilic lipase production by Halomonas sp. LM1C cultures. Bioresour. Technol. 239: 368-377.

45. Gao B, Su E, Lin J, Jiang Z, Ma Y, Wei D. 2009. Development of recombinant Escherichia coli whole-cell biocatalyst expressing a novel alkaline lipase-coding gene from Proteus sp. for biodiesel production. J. Biotechnol. 139: 169-175.

46. Korman TP, Bowie JU. 2012. Crystal Structure of Proteus mirabilis Lipase, a novel lipase from the proteus/psychrophilic subfamily of lipase family I.1. PLoS One 7: e52890.

47. Kovacic F, Babic N, Krauss U, Jaeger K. 2019. Classification of lipolytic enzymes from bacteria. pp. 1-35. Aerobic utilization of hydrocarbons, oils and lipids, Springer.

48. Gao B, Xu T, Lin J, Zhang L, Su E, Jiang Z, et al. 2011. Improving the catalytic activity of lipase LipK107 from Proteus sp. by sitedirected mutagenesis in the lid domain based on computer simulation. J. Mol. Cataly. B-Enzym. 68: 286-291.

49. Kim HK, Park YS, Kim H, Oh TK. 1996. Partial interfacial activation of Proteus vulgaris lipase overexpressed in Escherichia coli. Biosci. Biotechnol. Biochem. 60: 1365-1367.

50. Liu W, Li M, Yan Y. 2017. Heterologous expression and characterization of a new lipase from Pseudomonas fluorescens PfO-1 and used for biodiesel production. Sci. Rep. 7: 1-11.

51. Van Oort MG, Deveer AMTJ, Dijkman R, Tjeenk ML, Verheij HM, De Haas GH, et al. 1989. Purification and substrate specificity of Staphylococcus hyicus lipase. Biochem. 28: 9278-9285.

52. Ayala-Bribiesca E, Turgeon SL, Britten M. 2017. Effect of calcium on fatty acid bioaccessibility during in vitro digestion of Cheddar-type cheeses prepared with different milk fat fractions. J. Dairy. Sci. 100: 2454-2470.

53. Torcello-Gómez A, Boudard C, Mackie AR. 2018. Calcium alters the interfacial organization of hydrolyzed lipids during intestinal digestion. Langmuir 34: 7536-7544.

54. Alvarez FJ, Stella VJ. 1989. The role of calcium ions and bile salts on the pancreatic lipase-catalyzed hydrolysis of triglyceride emulsions stabilized with lecithin. Pharm. Res. 6: 449-457.

55. El Khattabi M, Van Gelder P, Bitter W, Tommassen J. 2003. Role of the calcium ion and the disulfide bond in the Burkholderia glumae lipase. J. Mol. Catal. B: Enzym. 22: 329-338.

56. Hertadi R, Widhyastuti H. 2015. Effect of $\mathrm{Ca}^{2+}$ Ion to the activity 
and stability of lipase isolated from Chromohalobacter japonicus BK-AB18. Procedia. Chem. 16: 306-313.

57. Invernizzi G, Papaleo E, Grandori R, De Gioia L, Lotti M. 2009. Relevance of metal ions for lipase stability: Structural rearrangements induced in the Burkholderia glumae lipase by calcium depletion. J. Struct. Biol. 168: 562-570.

58. Martigne M, Julien R, Sarda L. 1987. Studies on the effect of bile and lipolysis products on pancreatic lipase and colipase activity in vitro. Reprod. Nutr. Dev. 27: 1005-1012.

59. Borgström B. 1977. The action of bile salts and other detergents on pancreatic lipase and the interaction with colipase. Biochim. Biophys. Acta (BBA) - Lipids Lipid Metabolism 488: 381-391.

60. Borkar PS, Bodade RG, Rao SR, Khobragade CN. 2009. Purification and characterization of extracellular lipase from a new strain: Pseudomonas aeruginosa SRT 9. Braz. J. Microbiol. 40: 358-366.

61. Ye P, Xu YJ, Han ZP, Hu PC, Zhao ZL, Lu XL, et al. 2013. Probing effects of bile salt on lipase adsorption at air/solution interface by sum frequency generation vibrational spectroscopy. Biochem. Eng. J. 80: 61-67.

62. Hadvary P, Sidler W, Meister W, Vetter W, Wolfer H. 1991. The lipase inhibitor tetrahydrolipstatin binds covalently to the putative active site serine of pancreatic lipase. J. Biol. Chem. 266: 2021-2027.

63. Lüthi-Peng Q, Märki HP, Hadváry P. 1992. Identification of the active-site serine in human pancreatic lipase by chemical modification with tetrahydrolipstatin. FEBS Lett. 299: 111-115.

64. Qi X. 2018. Review of the clinical effect of orlistat. IOP Conf. Ser. Mater. Sci. Eng. 301: 012063.

65. Sternby B, Hartmann D, Borgstroöm B, Nilsson Å. 2002. Degree of in vivo inhibition of human gastric and pancreatic lipases by Orlistat (Tetrahydrolipstatin, THL) in the stomach and small intestine. Clin. Nutr. 21: 395-402.

66. Kelley DE, Bray GA, Pi-Sunyer FX, Klein S, Hill J, Miles J, et al. 2002. Clinical efficacy of orlistat therapy in overweight and obese patients with insulin-treated type 2 diabetes: a 1-year randomized controlled trial. Diabetes Care 25: 1033-1041.

67. Ben Ayed S, Ali MB, Bali A, Gargouri Y, Laouini D, Ben Ali Y. 2018. Secretory lipase from the human pathogen Leishmania major: Heterologous expression in the yeast Pichia pastoris and biochemical characterization. Biochimie 146: 119-126.

68. Salah RB, Mosbah H, Fendri A, Gargouri A, Gargouri Y, Mejdoub H. 2006. Biochemical and molecular characterization of a lipase produced by Rhizopus oryzae. FEMS Microbiol. Lett. 260: 241-248.

69. Zouari N, Miled N, Cherif S, Mejdoub H, Gargouri Y. 2005. Purifica- tion and characterization of a novel lipase from the digestive glands of a primitive animal: the scorpion. Biochim. Biophys. Acta (BBA) - General Subjects 1726: 67-74.

70. Luthi-peng Q, Winkler FK. 1992. Large spectral changes accompany the conformational transition of human pancreatic lipase induced by acylation with the inhibitor tetrahydrolipstatin. Eur. J. Biochem. 205: 383-390.

71. Minovska V, Winkelhausen E, Kuzmanova S. 2005. Lipase immobilized by different techniques on various support materials applied in oil hydrolysis. J. Serbian Chem. Soc. 70: 609-624.

72. Rosu R, Uozaki Y, Iwasaki Y, Yamane T. 1997. Repeated use of immobilized lipase for monoacylglycerol production by solidphase glycerolysis of olive oil. J. Am. Oil. Chem. Soc. 74: 445-450.

73. Kharrat N, Ali YB, Marzouk S, Gargouri YT, Karra-Châabouni M. 2011. Immobilization of Rhizopus oryzae lipase on silica aerogels by adsorption: Comparison with the free enzyme. Process. Biochem. 46: 1083-1089.

74. Egwim EC, Adesina AA, Oyewole OA, Okoliegbe IN. 2012. Optimization of lipase immobilized on chitosan beads for biodiesel production. Global. Res. J. Microbiol. 2: 103-112.

75. Dong H, Li J, Li Y, Hu L, Luo D. 2012. Improvement of catalytic activity and stability of lipase by immobilization on organobentonite. Chem. Eng. J. 181: 590-596.

76. Mateo C, Palomo JM, Fernandez-Lorente G, Guisan JM, FernandezLafuente R. 2007. Improvement of enzyme activity, stability and selectivity via immobilization techniques. Enzym. Microb. Technol. 40: 1451-1463.

77. Sankaran R, Show PL, Chang JS. 2016. Biodiesel production using immobilized lipase: feasibility and challenges. Biofuel. Bioprod. Bior. 10: 896-916.

78. Narwal SK, Gupta R. 2012. Biodiesel production by transesterification using immobilized lipase. Biotechnol. Lett. 35: 479-490.

79. Taher H, Al-Zuhair S. 2016. The use of alternative solvents in enzymatic biodiesel production: a review. Biofuel. Bioprod. Bior. 11: 168-194.

80. Laane C, Boeren S, Vos K, Veeger C. 1987. Rules for optimization of biocatalysis in organic solvents. Biotechnol. Bioeng. 30: 81-87.

81. Gorman LAS, Dordick JS. 1992. Organic solvents strip water off enzymes. Biotechnol. Bioeng. 39: 392-397.

82. Religia $\mathrm{P}$, Wijanarko A. 2015. Utilization of $n$-hexane as co-solvent to increase biodiesel yield on direct transesterification reaction from marine microalgae. Procedia Environ. Sci. 23: 412-420.

83. Yusuf M, Athar M. 2015. Biodiesel Production Using Hexane as Co-Solvent. J. Biofuels 6: 88-91. 